\title{
THE LOGICAL ROLE OF THE ARGUMENT FROM TIME IN THE TAHĀFUT'S SECOND PROOF FOR THE WORLD'S PRE-ETERNITY
}

\section{INTRODUCTION}

Of the four proofs reported and discussed by Al-Ghazāli in his Tahäfut al-Faläsifah (The Collapse of the Philosophers) for the world's pre-eternity, the second proof 1 has generally been regarded as the argument from time, 2 and with some justification. For, to begin with, the proof makes use of Aristotle's argument in the Physics, $\mathbf{3}$ and this argument is logically central to the whole proof. Moreover, and perhaps for this very reason, the discussions that follow both in Al-Ghazālï's Tahäfut al-Falāsifah and Ibn Rushd's Tahäfut al-Tahäfut ${ }^{4}$ concentrate on this aspect of the proof, the argument from time. For time, according to the Aristotelian argument, is the measure of motion, and if time is eternal, motion must be eternal. The proof makes explicit what this in turn entails, the eternity of that which is in motion, i.e., the world. Al-Ghazalli in his response to the proof neither challenges the Aristotelian definition of time as the measure of motion 5 nor does he question the legitimacy of the inference of the eternity of motion from the eternity of time. $6 \mathrm{He}$ only argues that time and the world were created together: God precedes the world in a non-temporal sense of "before." " The rest of the discussions in the Tahäfuts take up this issue and debate the question whether time can have a beginning. 8 For Ibn Rushd, a first moment of time is impossible since the moment, the "now," unlike the physical point, is not static and must always have a "before" as well as an "after." 9

But this very pre-occupation with the nature of time detracts from the actual role the argument from time plays in the proof. For the proof has to be considered in the peculiar manner in which it is formulated in

1 Al-Ghazālì, Tahäfut al-Falāsifah, ed. M. Boựges (Beirut, 1927), pp. 51-52. This edition will be abbreviated "TF."

2 Ai-Ghazāti himself seems so to regard it. $T F$, p. 80 .

3 Phy'sics, viii, Ch. I, 251b ro.

4 TF. pp. 52-66; Ibn Rushd, Tahăfut al-Tahäfut, ed. M. Bouyges (Beirut, 1930), pp. 64-97. This work will be abbreviated "TT."

$\overline{\bar{y}}$ Al-Ghazāli gives a subjective theory of time. TF, pp. $54 \mathrm{ff}$. But this does not necessarily rule out the theory that time is the measure of motion. See Itn Rushd's comment on AI-Ghazāli's theory. TT, pp. 73-74.

- See G. F. Hourani, "The Dialogue between Al-Glazāli and the Philosophers on the Origin of the World," The Muslim World, XLVIII, No. 3 (Iuly, 1958), pp. 189-90, and St. Thomas aquinas, Summa Contra Gentiles, Bk. II, Ch. 36, Sec. 6.

T TF, pp. 52-53.

$s$ This includes a second proof of the philosophers to demonstrate time's past eternity and its debate. TF, pp. 6o-66; TT, pp. 83-97.

$9 T \tilde{T}, \mathrm{pp} .76-80$. 
the Tahäfut. Al-Ghazāii did not reproduce the Aristotelian argument pure and simple. His source is Ibn Sinā's argument in his Najät, 10 and it is this formulation of Ibn $\operatorname{Sin} a$ that we must contend with. It is true that Al-Ghazāli in reproducing Ibn Sinnā's proof effects some changes, elaborates and clarifies some points, and omits part of the argument relegating it to another place in the subsequent discussion. ${ }^{11}$ But he is faithful in giving the essence of Ibn Sinā's argument, and, what to our purpose is most significant, in reproducing the logical structure of the proof 12 and in introducing the argument from time in the same manner that Ibn Sinā reproduced it. In both the Najät and the Tahäfut the argument from time is introduced in conjunction with the problem of God's priority to the world. The eternity of God is assumed throughout the proof and is used to argue for the eternity of time.

The entire proof in the Tahafut is formulated in such fashion that, taken at its face value, it does not constitute a proof at all. For it abounds with hidden premises and implied consequences-indeed, the proof's major conclusion, the world's pre-eternity, is implied, as we shall show. It is only when these hidden premises and implied consequences are fully drawn out that the proof can be exhibited for what it actually is, a syllogism of a specific type. The argument from time is only part of this syllogism. In itself it is not a conclusive argument for the world's pre-eternity. What it does prove, however, is that God's priority cannot be temporal, and this, as we shall show, is the minor premise of the syllogism. When this is realized, the proof is absolved from what otherwise would be a glaring circularity. Moreover, it becomes clear that the central metaphysical issue in the proof is not the nature of time, but the nature of God's causality.

We will analyze the proof to exhibit its syllogistic structure and to bring out the points mentioned above. In our analysis we will not question the soundness of the argument from time in the proof. We will grant its soundness for the sake of argument since our main purpose is to demonstrate the logical role it plays in a larger syllogistic con-

${ }^{10} \mathrm{Ibn}$ Sinā, Al-Najät (Cairo, I938), pp. 256-57.

11 In the Tahafut God's priority to the world is either essential or temporal, and these, as we shall show, are exclusive. This exclusiveness is not at first sight clear in the Najat's proof. There Ibn Sinā says that God is prior to the world either in essence or in essence ( $d h \bar{a} t$ ) and time. The subsequent argument, however (where, incidentally, Ibn Sinā anticipates and gives an answer to Al-Ghazāli's theory that God"s precedence to the world and time only means the existence of one essence and then two essences without this implying a temporal relation $-T F$, pp. 52-53), shows that Ibn Sina did not mean to conjoin essential priority with temporal, lon Sina simply means that God is either prior essentially or prior in existence and time. Al-Ghazāli by omitting the verbal conjunction avoids the ambiguity, He îrther makes vivid by specific examples what Ihn Sinā means by essential prionis where cause and effect are simultaneous. Al-Ghazāli omits a large portion of Ibn Sinā's proof which consists of an analysis of the meaning of kãna, "was" in the statement that God "was" before the world, which for Ibn Sina implies the existence of time. This Al-Ghazāli reproduces in the subsequent discussion and criticizes it. $T F$, Dp. 5.3-54.

12 See helow, note 14. 
text. Moreover, in the proof God's eternity is spoken of as though it is an eternity in time. This is the point Ibn Rushd takes exception to in his immediate comment on the proof and which leads him to reject the proof as a undemonstrative argument. ${ }^{13}$ Again, we will not quarrel with the proof on this issue.

\section{THE STRUCTCRE OF THE PROOF}

The proof Al-Ghazãli reports in his Tahăfut and attributes to the philosophers runs as follows:

They claim that whoever asserts that the world is posterior to God and God prior to the world can only mean one of two things : 14

$\mathrm{He}$ can mean that God's priority to the world is essential, not temporal, like the priority of one to two which is a priority by nature although one and two can coexist in the same time; and like priority of cause to effect, as for example, the priority of a person's movement to the movement of his shadow that follows him, the hand's movement to the movement of the ring, and the hand's movement in water to the movement of the water. All these are examples of simultaneous movements but some are causes, some effects. For it is said that the shadow moves by the movement of the person and the water moves by the movement of the hand,

$13 T T$, pp. $64-6.5$.

14 The sequence of conditions in the Arabic text runs as follows:

"They claim that whoever asserts that the world is posterior to God and God prior to the world can only mean cither (imma) that His priority is essential, not temporal ... and if ( $f a$ in) this is what is meant by God's priority to the world then ... and if ( $w$ a in) it is meant that God is prior to the world. not essentially, but in time, then ..." (Italics mine.)

Instead of the expected "or," (wa immo or $a w$ ) that normally follows the first "either" (imma), the first condition is repeated in the first "and if" and the second alternative it given in the second "and if," or "and "when," "as we render it in our translation. But it is clear that the alternatives are two, are exclusive, as we shall show, and are restricted to this number. The expression la yakhlì, literally" "not empty of," which might be rendered "without exception" and which comes immediately after the first immo in the text, is used in disjunctive syllogisms to restrict the number of alternatives to those stated in the argument. The expression mannicat al-khulī, literally "that which prohibits emptiness," is used to designate the two out of the three kinds of disjunctive syllogisms discussed in Arabic philosophy whose alternatives are restricted. See below, p. 9 and note 18 .

The disjunctive form of the argument is very clear in Ibn Sinā's proof :

"Moreover, with what does the First precede his created acts? By His essence or by time? If by His essence alone ... then ... if He precedes the world, not in essence alone, but in essence and time in that He was without the world and motion ... then there was time before motion and time ..." (Italics mine.)

The disjunctive form is also very clearly brought out by Ibn Rushd in his brief summary and criticism of the proof:

"The substance of what they say is that God if He is prior to the world is either causally, not temporally, prior, as a person is prior to his shadow or is temporally prior as the builder is prior to the wall. and if His priority is like the priority of a person to his shadow then ... and if $\mathrm{He}$ is temporally prior then ..." TT, pp. 64-65, (Italics mine.) 
and it is not said that the person moves by the movement of the shadow and the hand by the movement of the water although these movements are simultaneous. If this is what is meant by God's priority to the world, then it follows necessarily that they are either both temporal or both eternal and it would be impossible for one to be eternal, the other temporal.

If, on the other hand, it is meant that God is prior to the world and time, not essentially, but in time, then before the existence of the world and time a time would have existed in which the world did not exist, inasmuch as nonexistence preceded existence, and God would have preceded the world by a long duration, limited in the direction of its ending but having no limit in the direction of its beginning. Thus before the existence of time, eternal time would have existed, and this is contradictory, and for this reason the affirmation of the finitude of time is repugnant. When, therefore, time, which is the expression of the measure of motion, is necessarily eternal, motion is necessarily eternal and that which is in motion and through whose duration in motion time endures is necessarily eternal.

A preliminary remark is necessary before we proceed to analyze the discourse above: On first sight one might take the last sentence above as the conclusion of the proof as a whole. But this would overlook the tentative nature of this conclusion. As formulated above, the argument for the eternity of time is not a deduction from the nature of time and motion as in Aristotle, and following him, Ibn Rushd, Maimonides, and Aquinas. ${ }^{15}$ It is not deduced from the argument that time must always have a "before" and an "after." It is deduced from the premise that God is eternal and the supposition of His temporal priority to the world.

The discourse above gives two alternative ways in which God might be prior to the world. The alternatives are restricted 16 and exclusive. They are exclusive because the discussion of essential priority in the first part of the discourse clearly shows that essential priority implies temporal co-existence. This necessarily excludes the temporal priority or posteriorly of one or the other. Many of the consequences of these two alternatives are drawn. But not all the consequences are made explicit. Moreover, some premises are left implied. The discourse, as it stands, without all its implied assumptions and consequences fully drawn out, constitutes only a hypothetical disjunctive proposition ( $q a-$ diy'yah shartiyyah munfasilah). 17 Hence, to exhibit the discourse for

15 TT, pp. 76-80: Maimonides, The Guide for the Perblexed, Introduction to the second part, propositions $x v$ and xxvi, and Ch. I4, "first method": Aquinas, Summa Contra Gentiles, Bk. II, Cl. 33, sec. 6.

16 See ahove, note 14.

17 See Al-Ghazālī, Maqāșid al-Falāsifa (Cairo, 19.36), p. I9. 
what it actually is, a syllogism, we must make explicit what lies implicit.

In the discussion of the first alternative, God's essential priority to the world, the explicit consequence is that such a priority implies temporal co-existence. If God is eternal, the world is eternal, and if God is temporal, the world is temporal. The implied premise here is that God is eternal. The assumption that God is eternal is made use of, as we shall see, in the discussion of the second alternative, God's temporal priority. To prove that the world is eternal, all that is necessary is to prove that God's priority is essential.

The argument from time comes in the discussion of the consequence of the second alternative, the supposition that God's priority is temporal. If we suppose God's priority temporal, the argument in essence states, then we must conclude that the world is eternal. For God would then precede the world by infinite time and infinite time implies the world's eternity. Clearly here we have the assumption that God is eternal; otherwise $\mathrm{He}$ would not precede the world by infinite time. Infinite time in turn implies the world's eternity since time is the measure of motion and does not exist without motion. But in such an argument we do not arrive at the world's eternity because as a matter of fact God temporally precedes the world. Indeed, $\mathrm{He}$ cannot. For if both God and the world are eternal, then God cannot precede the world by time. The argument here is a reductio ad absurdum: of we suppose God's priority temporal, we would have to conclude its contradictory that God's priority cannot be temporal. Hence, God's priority cannot be temporal. But this conclusion is left implicit, and yet, it is the conclusion which the argument from time, taken independently from what precedes it in the proof, actually proves. Independently, the argument from time as formulated in the Tahafut does not prove the world's eternity.

This is shown by the simple fact that one might insist that there can be another kind of priority which is not temporal and which would yet allow the creation of a world finite in its past temporal extension. Indeed, this is precisely what Al-Ghazäli insists upon in his rejection of the proof. Thus the argument from time would only prove the world's eternity if it is stipulated beforehand that there can be no other kind of priority which is non-temporal and which yet would allow a non-eternal world. And this is what the preceding parts of the proof stipulate. For the number of possible priorities are restricted to two, essential and temporal. Essential priority implies temporal co-existence of God and the world, so that if God is eternal, the world is eternal. That God is eternal is a premise assumed throughout the proof and accepted by all the disputants. Hence, without setting this condition, the argument from time does not prove the world's pre-eternity. But it does, taken independently, prove the impossibility of God's temporal priority to the world. It does that because any priority posited other 
than a temporal priority would in the very nature of the case not be a temporal priority.

Hence, the argument from time, independently of the rest of the proof, proves one thing: the impossibility of God's temporal priority. But what does this mean? It means that one of the two disjuncts in the disjunctive proposition has been proven false. But to deny one of the two disjuncts is to affirm the other. In effect we have here a fullfledged syllogism in which one disjunct is proved through the disproof of the other. And indeed we have here an example of the type of syllogism Ibn Sinā terms "a hypothetical 'truly' disjunctive syllogism" (qiyās istithnāiyy shartiyy munfasil haqiqatan) 18 in which the alternatives are restricted and exclusive and where, when, as in the case above, the alternatives are two, the denial of one results in the affirmation of the other, and the affirmation of one results in the denial of the other. The argument from time in effect, has proven that God's priority is essential, but only through this disjunctive syllogistic argument. The world's pre-eternity in turn is the implied consequence of the affirmation of God's essential priority and the hidden premise that God is eternal.

\section{FURTHER ANALYSIS}

Real and Apparent Circularity. - A circularity has been pointed out in the minor premise, in the Aristotelian argument: 19 To infer the eternity of motion from the eternity of time assumes the point at issue, the eternity of motion. For time is defined as the measure of motion. Hence, we can only infer the eternity of time from the eternity of motion. We cannot reverse the process and infer the eternity of motion from the eternity of time. This seems a just criticism of the Aristotelian argument. However, in this analysis, as we have pointed out, we are chiefly concerned with the structure of the proof as a whole and with the role the argument from time plays in the syllogism. Whether the argument from time is sound or not is important in itself. But it is not relevant to our purpose here.

However, there seems to be another circularity in the proof that

18 See Sinā, Kitāb al-Ishãrāt zua-l-Tanbìhāt, ed. J. Forget (Leyden, I892), pp. 29, 78-79.

The "truly" disjunctive syllogism is one that restricts the alternatives and prohibits conjunction: $n a \bar{n} i^{c}$ at al-khulit ara-l-jam ${ }^{c}$. The non truly disjunctive are two in number. The first of these restricts only but does not prohibit conjunction: manicat al-khulu faqat. This is identical with what is normally regarded nowadays as the disjunctive syllogism where the relation "or" is inclusive. Here only the denial of one of the two alternatives results in the affirmation of the other. The second type of non-truly disjunctive syllogism does not restrict the number of alternatives but prohibits conjunction: manic at al-jam ${ }^{c}$ faqat. Here only the aitirmation of one of the alternatives results in the denial of the rest. See also Al-Ghazāli. Micyār al-cilm (Cairo, I 329 A.H., pp. 65-66, 89-90, and Maliak al Ka-ar (Cairo, no date), pp. 42-44.

19 See above, note 6 . 
is relevant because it involves the structure of the proof as a whole. If the proof as a whole is regarded, as it should be, as a disjunctive syllogism, and if at the same time the argument from time is regarded as in itself proving both the impossibility of God's temporal priority to the world and the world's pre-eternity, then we are caught in the following circularity: The world's pre-eternity is the consequence of God's essential priority but this essential priority itself is a consequence of the world's pre-eternity.

But our analysis of the proof's structure absolves it from this circularity. For, as we have shown, the argument from time by itself does not prove the world's pre-eternity. It only proves that God's priority cannot be temporal. Hence, the essential priority of God is not deduced from the world's pre-eternity, and thus no circularity is involved.

The Centrality of the Disjunctive Form. - One might attempt to approach the proof differently and completely disregard the disjunctive form. One might concentrate on the argument from time and regard it as a proof for both the world's pre-eternity and God's essential priority. But this, to begin with, is not warranted by the very wording of the proof. Furthermore, it is not warranted logically. To begin with, the argument from time does not prove by itself the world's pre-eternity. However, if for the sake of argument we concede that it does, it would still have to show that God is prior to the world in the same sense that the discussion of God's essential priority in the proof says that God is prior. And this it does not do. For the argument from time would only prove that God and the world must co-exist if God is eternal. If God is supposed to be not eternal, $\mathrm{He}$ can be temporally prior to the world. For then He would not precede the world by infinite time. But in the discussion of essential priority in the proof God and the world must co-exist in the same time regardless of whether God is eternal or temporal. Indeed, if God is not eternal the world is not eternal precisely because it must co-exist with Him. This is implied by the very concept of essential priority discussed in the proof. Hence the argument from time would not show that God is prior to the world in the same sense as the discussion of essential priority in the proof says that God is prior. The argument from time, in effect, taken by itself, neither proves the world's eternity nor God's essential priority articulated in the proof. Hence, if we disregard the disjunctive form, we have no argument.

The Metaphy'sical Implications of the Proof. - Our last analysis above leads us into the metaphysical implications of the proof. The argument from time, if again, for the sake of argument, is to be regarded as in itself a proof for the world's pre-eternity, would say something quite different about the relation of God to the world. The reason for the impossibility of God's temporal priority to the world would lie in the fact that time, and hence the world, is eternal. The necessity lies outside God. It lies in the nature of time, motion, and the world. In 
effect, the argument says that God, if $\mathrm{He}$ creates at all, because of the nature of time, must create eternally. It does not say that God by His nature necessarily creates and, since $\mathrm{He}$ is eternal, His creation is necessarily eternal. Indeed, the concept of God as cause here is irrelevant. God need not be the cause of the world but if $\mathrm{He}$ is eternal the world would have to be eternal since otherwise $\mathrm{He}$ would precede the world by infinite time.

But the world's pre-eternity as a consequence of God's essential priority to the world relegates necessity to God. Here it is not merely the case that if God creates at all His creation must be eternal. Rather, God necessarily creates the world and His creation is therefore necessarily eternal. Otherwise why should the discussion of essential priority in the proof show that even if God is temporal the world must co-exist with Him? Clearly the notion of essential priority implies that God's act must be co-extensive with His being, and hence, the temporal posteriority of the world to God is impossible. Now, in the first proof and the discussions that follow it, several arguments were given to show the impossibility of the world's temporal posteriority to God, all, in one way or another, expressing determinism. We will list some of these: (1) The temporal posteriority of the world implies the occurrence of a determinant in time which in turn implies the occurrence of yet another determinant to explain the occurrence of the first, and the second determinent implies the existence of yet another determinant, and so on ad infinitum, and this is impossible. 20 (2) Temporal posteriority implies change in God. 21 (3) It implies the delay of the ef fect after the cause when where is no intervening obstacle. 22 (4) It implies choice between exactly similar moments of time when there is nothing to differentiate and specify one moment from another. 23 Of these, (3) indicates the doctrine that God necessarily creates, implied in the proof above, and indeed it is this issue which Ibn Rushd brings up again in his answer to Al-Ghāzāli's theory that the world and time were created together at a finite moment in the past. $24 \mathrm{~A}$ cause with all its conditions fulfilled must have its effect, and if there is no obstacle the effect cannot be delayed. Now in the case of God the cause is the Divine Will. The Divine Will is eternal. Moreorer, for the philosophers (as well as for the $\mathrm{Mu}^{\mathrm{c}}$ tazila) the Divine Will is identical with the Divine Essence, and for Ibn Sina the Divine Essence and the Divine Existence are one and the same. Hence God by His very Essence creates the world. The world is the necessitated effect of an eternal changeless cause, and hence must be eternal. It cannot be temporally posterior to God.

\footnotetext{
$20 T F$, p. 23.

$21 T F$, pp. $23,25,27$.

$22 T F$, pp. 26-29.

$23 T F$, pp. $36-37$.

$24 T T$, p. 68 .
} 
This is further betrayed by the illustrations of simultaneous cause and effect that Al-Ghazali gives in the discussion of essential priority. These examples appear elsewhere in Al-Ghazalin's Tahäfut and other writings 25 and come in discussions of necessary causation and of voluntary as against necessary acts. In particular, the illustration of the shadow's movement that is simultaneous with the movement of the person suggests what was in the mind of Al-Ghazàli when he gave that example. That the shadow is the necessary consequence of a man is given by Al-Ghazāli at the beginning of the third discussion. There Al-Ghazāli attacks the philosophers' theory that God creates by necessity. In explaining what the philosophers mean by this Al-Ghazâli reports that the philosophers think that God must create the world just as the sun must give its light and just as the person necessitates his shadow. 26

Thus, in the proof, the central metaphysical issue is the nature of God's causality rather than the nature of time, and it is the nature of God's causality that is the fundamental issue in conflict between the philosophers and the Ashcarites. 27

\section{SUMMARY}

The proof is a disjunctive syllogism, and only as a disjunctive syllogism can it be regarded as a complete argument for the world's preeternity. The argument from time in itself does not prove the world's pre-eternity. What it does prove, is that God's priority cannot be temporal, so disproving one of the two alternatives in the premise. By disproving this alternative, it proves the other, God's essential priority. The conclusion that the world is eternal is a consequence of this and the implied premise that God is eternal. When it is shown that the argument from time in itself does not prove the world's pre-eternity, the proof is absolved from an apparent circularity. Analysis shows that the central metaphysical issue in the proof is not the nature of time, but rather the nature of God's causality.

$$
\begin{aligned}
& \text { University of Michigan, } \\
& \text { Ann Arbor, Michigan }
\end{aligned}
$$

\footnotetext{
25 TF, pp. 107-9; Al-Iqtisāad fi-l-Ictiqād (Cairo, no date), pp. 45-46.

$20 T F$, p. 97.

27 For an incisive treatment of this issue see Majid Fakhry, Islamic Occasionalism (London, 1958).
} 